\title{
HUMAN CORONAVIRUS-NL63 INFECTION IS NOT ASSOCIATED WITH ACUTE KAWASAKI DISEASE
}

\author{
S. C. Baker, C. Shimizu, H. Shike, F. Garcia, L. van der Hoek,
}

T. W. Kuijper, S. L. Reed, A. H. Rowley, S. T. Shulman, H. K. B. Talbot, J. V. Williams, and J. C. Burns*

\section{INTRODUCTION}

Kawasaki disease (KD) is an acute, systemic vasculitis generally seen in early childhood. KD particularly affects medium size arteries, such as coronary arteries, and can result in coronary artery aneurysms that rupture, causing sudden death. The clinical and epidemiologic features of KD, with acute onset of fever, rash, conjunctival injection and cervical adenitis, and focal epidemics with wave-like spread of illness, are consistent with an infectious etiology (reviewed in Ref. 1). Indeed, current studies provide evidence that the $\operatorname{IgA}$ response in $\mathrm{KD}$ is targeting antigen in the bronchial epithelium and other inflamed tissues. ${ }^{2,3}$ However, conventional methods have failed to identify the etiology of KD. Recently, Esper and colleagues reported an association between KD and a RNA virus they termed $\mathrm{HCoV}-\mathrm{New}$ Haven $(\mathrm{NH}){ }^{4}$ The limited sequence currently available indicates that $\mathrm{HCoV}-\mathrm{NH}$ is highly similar to $\mathrm{HCoV}-\mathrm{NL} 63$, which was initially described in 2004. ${ }^{5}$ To determine if HCoV-NL63 was associated with KD, we established a multiinstitutional collaborative study to test respiratory samples from KD patients using RTPCR methods. We found that only 1 of $48 \mathrm{KD}$ patients $(2 \%)$ was positive for HcoVNL63. Thus, these results indicate that respiratory tract infection with HcoV-NL63 is not associated with acute KD. A detailed description of all methods and results is provided in Ref. 6.

\footnotetext{
* S. C. Baker, Loyola University Chicago Stritch School of Medicine, Maywood, Illinois. C. Shimizu, H. Shike, S. L. Reed, J. C. Burns, University of California San Diego School of Medicine, La Jolla, California. F. Garcia, A. H. Rowley, S. T. Shulman, Northwestern University Feinberg School of Medicine, Chicago, Illinois. L. van der Hoek, T. W. Kuijper, Academic Medical Center, Amsterdam, The Netherlands. H. K. B. Talbot, J. V. Williams, Vanderbilt University Medical Center, Nashville, Tennessee.
} 


\section{HUMAN SUBJECTS, MATERIALS, AND METHODS}

Two centers in the U.S. (Children's Hospital of San Diego, San Diego, CA; Children's Memorial Hospital, Chicago, IL) and one center in The Netherlands (Academic Medical Center (AMC), Amsterdam) collected respiratory samples from KD patients between December 2000 and March 2005. Seventy-seven percent of the samples were collected during the winter/spring months, which are seasons when $\mathrm{HCoV}$ is prevalent. Respiratory samples included throat swabs, nasopharyngeal (NP) swabs, scraped NP epithelial cells, and nasal washings were either archived or collected prospectively specifically for this study. Inclusion criteria for children with $\mathrm{KD}$ were more than five days of fever plus four of five standard clinical criteria (rash, conjunctival injection, cervical lymphadenopathy, changes in the extremities, changes in lips or oral mucosa) or three of five criteria with dilated coronary arteries by echocardiogram ( $\mathrm{z}$ score $>2.5$ ). The research protocol was reviewed and approved by the Institutional Review Boards of each institution. Informed consent was obtained from the parents of all subjects.

RT-PCR analysis was performed on RNA isolated from KD patient respiratory samples using primers and methods described in detail in Ref. 6. Degenerate primers were included to detect HCoV-NL63 variants. Samples were also tested using primers for human cellular mRNA sequences such as beta actin, to ensure the quality of the extracted RNA. A schematic diagram of the HCoV-NL63 genome and relative position of the 18 different primers sets used in this study is shown in Figure 1.

\section{RESULTS AND DISCUSSION}

We tested a total of 57 samples from $48 \mathrm{KD}$ patients and found that only one of the $48 \mathrm{KD}$ patients $(2 \%)$ was positive for HCoV-NL63 RNA (Table 1). This patient met 4 of 5 classic clinical criteria for $\mathrm{KD}$, but also exhibited symptoms of an upper respiratory tract infection, with cough and coryza which are rare symptoms for KD but common symptoms for HCoV-NL63 infection. Furthermore, although this patient responded with complete defervescence after administration of intravenous gamma globulin and aspirin that are common treatments for $\mathrm{KD}$, his respiratory symptoms persisted. These results suggest that this KD patient was likely co-infected with HCoV-NL63.

Recent studies from Japan ${ }^{7}$ and the Centers for Disease Control and Prevention in the $\mathrm{USA}^{8}$ also report no association between infection with HCoV-NL63 and acute KD. Interestingly, a large study of pediatric patients in Europe found that HCoV-NL63 infection is associated with croup. ${ }^{9}$ Thus, although HCoV-NL63 is likely a common respiratory infection in children, we and others found no association with acute KD.

\section{CONCLUSION AND FUTURE DIRECTIONS}

We found no association between the detection of HCoV-NL63 genome in the respiratory tract and acute KD. Future studies should continue to address the possibility of a microbe with a respiratory portal of entry as the etiologic agent of KD. 


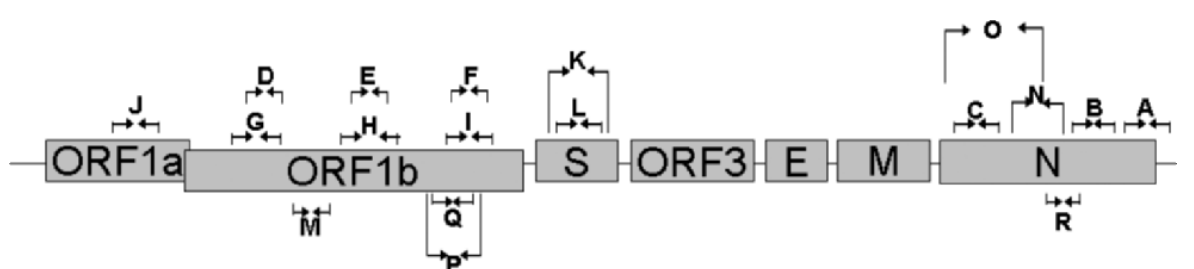

Figure 1. Schematic diagram of the organization of HCoV-NL63 genome and the locations of primers used tor RT-PCR analysis. Shaded box are open reading frames. Primer sets are shown by arrow sets A-R. [Reproduced with permission from Shimizu et al., "Human coronavirus NL63 is not detected in the respiratory tract of children with acute Kawasaki disease”, The Journal of Infectious Diseases 2005; 192: 1767-1771].

Table 1. Results of HCoV RT-PCR on respiratory samples from acute Kawasaki disease patients. ${ }^{\mathrm{a}}$

\begin{tabular}{|c|c|c|c|c|c|c|c|c|c|c|c|c|}
\hline \multirow{2}{*}{$\begin{array}{l}\text { Location } \\
\text { of sample } \\
\text { collection }\end{array}$} & \multirow{2}{*}{$\begin{array}{c}\text { No. of } \\
\text { patients } \\
\text { samples }\end{array}$} & \multicolumn{2}{|c|}{$\begin{array}{c}\text { HCoV } \\
\text { RT-PCR }\end{array}$} & \multicolumn{3}{|c|}{ Patient } & \multicolumn{6}{|c|}{ Sample } \\
\hline & & \begin{tabular}{|c|} 
Pos. \\
sample
\end{tabular} & $\begin{array}{c}\text { Primer } \\
\text { sets }^{\text {d }}\end{array}$ & $\begin{array}{c}\text { Age } \\
\text { median }\end{array}$ & Males & $\mathbf{C A A}^{\mathrm{e}}$ & \begin{tabular}{|c|} 
Throat \\
swab
\end{tabular} & $\begin{array}{c}\text { NP } \\
\text { swab }\end{array}$ & $\begin{array}{c}\text { Scraped } \\
\text { NP } \\
\text { cells }\end{array}$ & $\begin{array}{l}\text { Nasal } \\
\text { wash }\end{array}$ & $\begin{array}{c}\text { Illness } \\
\text { Day }^{f} \\
\text { (median) }\end{array}$ & $\begin{array}{c}\text { Samples } \\
\text { post- } \\
\text { IVIG }\end{array}$ \\
\hline $\begin{array}{l}\text { CA, } \\
\text { USA }\end{array}$ & $17(23)$ & 1 & A-J & $\begin{array}{l}2 \mathrm{~m}-9 \mathrm{y} \\
(30 \mathrm{~m})\end{array}$ & 15 & $1 / 6$ & 8 & 7 & 8 & 0 & $\begin{array}{l}3-15 \\
(6.5)\end{array}$ & 2 \\
\hline \multirow[t]{2}{*}{$\begin{array}{c}\text { IL, } \\
\text { USA }\end{array}$} & $13^{\mathrm{b}}(15)$ & 0 & $\mathrm{~J}-\mathrm{O}$ & \begin{tabular}{|c|}
$4 \mathrm{~m}-10 \mathrm{y}$ \\
$(38 \mathrm{~m})$
\end{tabular} & 11 & $1 / 5$ & 13 & 0 & 2 & 0 & $\begin{array}{l}4-9 \\
(6)\end{array}$ & 0 \\
\hline & $12^{\mathrm{c}}(12)$ & 0 & A-C & $\begin{array}{l}4 \mathrm{~m}-6 \mathrm{y} \\
(12 \mathrm{~m})\end{array}$ & 11 & $1 / 3$ & 12 & 0 & 0 & 0 & $\begin{array}{c}3-9 \\
(6.5)\end{array}$ & 0 \\
\hline NL & $7(7)$ & 0 & $\begin{array}{l}\text { P-R, } \\
\text { J-L }\end{array}$ & $\begin{array}{l}5 \mathrm{~m}-9 \mathrm{y} \\
(35 \mathrm{~m})\end{array}$ & 5 & $1 / 2$ & 0 & 0 & 0 & 7 & $\begin{array}{l}4-9 \\
(7)\end{array}$ & 2 \\
\hline Total & $48(57)$ & 1 & & $\begin{array}{c}2 \mathrm{~m}-10 \mathrm{y} \\
(31 \mathrm{~m})\end{array}$ & 42 & $4 / 16$ & 33 & 7 & 10 & 7 & $\begin{array}{c}3-15 \\
(7)\end{array}$ & 4 \\
\hline
\end{tabular}

${ }^{a}$ Reproduced with permission from Shimizu et al., "Human coronavirus NL63 is not detected in the respiratory tract of children with acute Kawasaki disease", The Journal of Infectious Diseases 2005; 192: (in press).

${ }^{\mathrm{b}}$ Samples analyzed at Northwestern University and Loyola University, one sample was also tested at Vanderbilt University.

${ }^{\mathrm{c}}$ Samples analyzed at Vanderbilt University, one sample was also tested at Northwestern University and Loyola University.

${ }^{\mathrm{d}}$ Primer sets A-C, N, O, R = primer sets from HCoV-NL63 nucleocapsid protein gene, D-F, M, and P with nested primer st $\mathrm{Q}=$ primer sets from HCoV-NL63 ORF1b; J = primer sets from HCoV-NH ORF1a; K with nested primer set $\mathrm{L}=$ primer sets from $\mathrm{HCoV}-\mathrm{NH}$ spike glycoprotein gene. $\mathrm{G}-\mathrm{I}=$ degenerate primer sets from conserved regions of the ORF1b shared by HCoV-NL63, severe acute respiratory syndrome (SARS)-CoV (NC_004718), HCoV-E229 (NC_002645), and HCoV-OC43 (NC_005147).

${ }^{\mathrm{e}} \mathrm{CAA}=$ coronary artery abnormality, patients with aneurysms/ patients with dilatation (internal lumen $\mathrm{z}$ score $>2.5$.

${ }^{\mathrm{f}}$ Illness Day 1 = first day of fever.

\section{ACKNOWLEDGMENTS}

We thank Drs. Ralph Baric, Michael Buchmeier, Benjamin Neuman, Ron Fouchier, and Christian Drosten for providing materials and technical advice. We also thank Joan Pancheri RN, UCSD, for assistance in collection of clinical samples. This work supported in part by grants from the National Institutes of Health (RO1 HL69413 to J.C.B., AI45798 to S.C.B., and HL63771 and HL67011 to A.H.R.). 


\section{REFERENCES}

1. Rowley, A. H., 2004, Kawasaki Syndrome, in: Krugman's Infectious Diseases of Children, A. A. Gershon, P. J. Hotez, S. L. Katz, eds., Mosby, Philadelphia, pp. 323-335.

2. Rowley, A.H., Baker, S. C., Shulman, S. T., Garcia, F. L., Guzman-Cottril, J. A., Chou, P., Terai, M., Kawasaki, T., Kalelkar, M. B., and Crawford, S. E., 2004, Detection of antigen in bronchial epithelium and macrophages in acute Kawasaki disease by use of synthetic antibody, J. Infect. Dis. 190:856-865.

3. Rowley, A.H., Baker, S. C., Shulman, S. T., Fox, L., Takahashi, K., Garcia, F. L., Crawford, S. E., Chou, P. and Orenstein, J. M., 2005, Cytoplasmic inclusion bodies are detected by synthetic antibody in acute Kawasaki disease ciliated bronchial epithelium, J. Infect. Dis. 192: 1757-1766.

4. Esper, F., Shapiro, E. D., Weibel, C., Ferguson, D., Landry, M. L., and Kahn, J. S., 2005, Association between a novel human coronavirus and Kawasaki disease, J. Infect. Dis. 191:499-502.

5. van der Hoek, L., Pyrc, K., Jebbink, M. F., Vermeulen-Oost, W., Berkhout, R. J. M., Wolthers, K. C., Wertheim-van Dillen, P. M. E., Kaandorp, J., Spaargaren, J., and Berkhout, B., 2004, Identification of a new human coronavirus, Nat. Med. 10:368-373.

6. Shimizu, C., Shike, H., Baker, S. C., Garcia, F., van der Hoek, L., Kuijpers, T. W., Reed, S. L., Rowley, A. H., Shulman, S. T., Talbot, H. K. B., Williams, J. V., and Burns, J. C., 2005, Human coronavirus NL63 is not detected in the respiratory tract of children with acute Kawasaki disease, J. Infect. Dis. 192: 1767-1771.

7. Ebihara, T., Endo, R., Ma, X., Ishiguro, N., and Kikuta, H., 2005, Lack of association between New Haven coronavirus and Kawasaki disease, J. Infect. Dis. 192:351-352.

8. Belay, E. D., Erdman, D. D., Anderson, L. J., Peret, T. C. T., Schrag, S. J., Fields, B. S., Burns, J. C., and Schonberger, L. B., 2005, Kawasaki disease and human coronavirus, J. Infect. Dis. 192:352-353.

9. van der Hoek, L., Sure, K., Ihorst, G., Stang, A., Pyrc, K., Jebbink, M. F., Petersen, G., Porster, J., B. Berkhout, B., and Uberla, K., 2005, Croup is associated with the novel coronavirus NL63, PloS Med. 2:e240. 